автореф. дис. ... канд.филол.наук: спец. 10.02.04 «Германские языки»; ИГУ, 1999. 22 с.

4. Сорокин Ю. А., Тарасов Е. Ф. Креолизованные тексты и их коммуникативная функция. Оптимизация речевого воздействия. Москва, 1990. C. $180-181$.

5. ArtOfQuarantine. URL: https://madmap.com.ua/projects/art-ofquarantine (дата звернення 16.02.2021).

6. Berezov A. Coronavirus and the Ethics of 'Pandemic Porn'. URL: https://www.acsh.org/news/2020/05/28/coronavirus-and-ethics-pandemic-porn-14818 (дата звернення 19.02.2021).

7. MMD. URL: https:// www.macmillandictionary.com/buzzword/ entries/infobesity.html\#:-:text (дата звернення 18.02.2021).

8. MWD. URL: https://www.merriem-webster.com/words-at-play/wordswere-watching-infodemic-meaning (дата звернення 18.02.2021).

9. Yurieva E. V. Verbal and Non-verbal Techniques of Creating the Comic in Creolized Texts of Social Advertisement. Izv. Saratov Univ. (N. S.), Ser. Philology. Journalism, 2017. Vol. 17. iss. 1, P. 24-28 (in Russian). DOI: 10.18500/1819-7663-2017-17-1-24-28.

DOI https://doi.org/10.30525/978-9934-26-039-1-52

\title{
LINGUOSTYLISTIC PECULIARITIES OF POETIC DISCOURSE
}

\author{
Chendey N. V. \\ Ph. D. in Philology, \\ Associate Professor at the English Philology Department \\ Uzhhorod National University \\ Uzhhorod, Ukraine
}

Poetic discourse is defined as linguistic and mental space created by the author and his/her reader by means of a poetic text that combines three aspects: linguistic, communicative and cognitive [1, p. 6].

The linguistic aspect is embodied in a poetic text itself (hereinafter - PT) by thoroughly selected language means that can be perceived sensitively.

The communicative aspect is revealed in a dialogue between the author and reader of a PT in which a poetic function of language prevails and defines the implication of a vast range of linguostylistic devices.

The cognitive aspect deals with the verbalization of artistic concepts. Discourse concepts configuration is defined as a totality of key concepts that 202 
belong to various concept fields of a national conceptual sphere and verbalized in a given discourse by linguistic means [2].

Thus, it has been hypothetically suggested that stylistic devices (phonetic, lexical, syntactical and textual) provoke triggers in the reader's consciousness, i.e. the verbalization of artistic concepts and their implications on the basis of cognitive operations. [5, p. 50] Correspondingly, triggers are linguistic means of different levels (phonetic, lexical, morphological and syntactical) due to which the artistic concepts and their implications are realized in a discursive context. The term «trigger» has been borrowed from linguistic pragmatics where this term designates a language unit that initiates a definite implicit meaning (S. Levinson).

In this research the attempt has been made to identify features of poetic discourse in general and to study linguostylistic devices as triggers of some verbal poetic images and artistic concepts in E. Dickinson's lyric-poetic discourse in particular.

Phonetic stylistic devices such as alliteration, assonance, consonance and caesura are considered to be triggers of the verbal poetic images and artistic concepts in E. Dickinson's poetic discourse.

Alliteration is defined as the use of two words or more in close proximity that begin with the same consonant sound. Emily Dickinson uses alliteration in her poem «Fame is a fickle food» to actualize FAME that ultimately destroys whoever «eats» it. "Fame is a fickle food Upon a shifting plate Whose table once a Guest but not The second time is set. Whose crumbs the crows inspect». Alliteration is used in the first line of each stanza in the poem to emphasize FAME and its fleeting, entirely unpredictable nature. Using the lexemes «fame» and «fickle food» deeply accentuates the fact that while these notions can hardly be associated, they create a context for realizing the verbal poetic image of fame that fades away. This is highlighted by the next three lines in the stanza «Whose table once a Guest but not The second time is set》, which literary means that fame is unstable. Alliteration adds to an empty and lamented tone of the poem, being intensified by the irony in the caw and crows that are smart enough to figure out that fame, unlike corn, is not filling, nourishing. Humans, however, take fame over worthwhile things, which makes them lose sights of their former selves [6].

Consonance refers to repetitive sounds produced by consonants within a sentence or phrase. This stylistic device may be exemplified by the lines in which Emily Dickinson has made use of the consonant $/ \mathrm{m} /$ frequently in the underlined words: «Twas later when the summer went/ Than when the Cricket came - / And yet we knew that gentle Clock / Meant nought but going Home- 
Twas sooner when the Cricket went/ Than when the Winter came /Yet that pathetic pendulum Keeps esoteric Time».

The poetess generally makes use of consonance in an attempt to underscore the emotions behind her words that simple words cannot convey. Another poem by Dickinson that makes good use of consonance is "As imperceptibly as Grief». "A Quietness distilled As Twilight long begun, Or Nature spending with herself Sequestered Afternoon $\rightarrow$. Here Emily Dickinson has relied on the consonant «n» to create the intended effect. The poem is a deceptively simple meditation on the nature of TIME. It compares grief to summer, suggesting that people don't always notice the way that everything undergoes gradual change - but nothing in life stays still. The poetic image of DEATH is implicitly felt as the poem gently reminds the reader that LIFE is fleeting - the passage of TIME eventually brings all life to its inevitable end, but it does it so gradually, in a way similar to the returning of summer into autumn.

Alliteration occurs at two moments in «As imperceptibly as Grief». It is first used in line 9 with «dusk drew», both beginning with /d/ sounds. The effect is subtle but it conjures the idea of the day being covered with darkness. Lines 11 and 12 then feature three/g/ sounds «grace» «guest» and «gone». This links the three words together conceptually, and as they are the main examples of $/ \mathrm{g} /$ create a sense of presence that is absent elsewhere. This embodies the idea of something or someone arriving, and then departing. The /g/ sound here echoes its first appearance in line 1 - «grief»». The idea of departure becomes linked to the feeling of loss, supporting the poem's overall proposition that loss is everywhere in everyday reality nothing can last forever.

Emily Dickinson's poem, «I heard a Fly buzz - when I died», is told by a woman who is still speaking and still hearing things upon her death. The alliteration of /st/ connects the words «stillness» and «storm». Conceptually, these two words are at odds, and yet in context Dickinson is referring to the calm that occurs in the middle of storms, such as the eye of the hurricane. The stillness at those times is more profound that at other times, and this connection between stillness and storm is highlighted by her use of alliteration.

Caesura is a rhythmic break or pause in the flow of sound which is commonly introduced in about the middle of a line of verse, but may be varied for different effects. Typically placed between syllables, rhythmically connected in order to aid the recital as well as to convey the meaning more clearly, it is a pause dictated by the sense of the content or by natural speech patterns, rather than by metrics. It may coincide with conventional punctuation marks, but not necessarily. A caesura within a line is indicated in scansion by 
the parallel symbol $(\|)$, as in the first line of Emily Dickinson's «I'm Nobody! Who Are You?»: I'm no | body! || Who are | you? As a grammatical, rhythmic, and dramatic device, as well as an effective means of avoiding monotony, the caesura is a subtle but effective weapon in the skilled poetess's arsenal.

Having considered linguistic and conceptual features of Emily Dickinson's poetic discourse, we have concluded that it is unique due to the poetess' cognitive style which proves to be deprived of biased traditional canons, but through the self-isolation provides the non-canonical view of spiritual values which find expression in the conceptual content of most poetic images. The prevalence of emotiveness and accuracy of key images put a prime focus on reader's perception and sensitive experience.

\section{References:}

1. Остапченко В. О. Лінгвокогнітивні та прагмастилістичні властивості лірико-поетичного дискурсу Р. М. Рільке : автореф. дис. ...канд. філол. наук :10.02.04 - германські мови. Харків, 2019. 20 с.

2. Приходько А. М. Концепти і концептосистеми в когнітивнодискурсивній парадигмі. Запоріжжя : Прем'єр, 2008. 331 с.

3. Dickinson E. The Selected Poems by Emily Dickinson. Hertfordshire : Wordsworth Editions Ltd, 1994. 214 p.

4. Langacker R. W. Concept, Image and Symbol : The Cognitive Basis of Grammar. Berlin, N.Y. : Mouton de Gruyter, 1990. 546 p.

5. Levinson S. C. Pragmatics. Cambridge: Cambridge University Press, 1983. $420 \mathrm{p}$.

6. Alliteration Examples and Definition - Literary Devices http://www.literarydevices.com/alliteration/ 